\title{
ANALISIS PENGARUH KUALITAS PRODUK, HARGA, PELAYANAN DAN LOKASI TERHADAP KEPUTUSAN KONSUMEN RUMAH MAKAN ADITYA JAYA DI KABUPATEN ACEH BESAR
}

(An Analysis Of The Impact Of Product Quality, Price, Service And Location Toward Consumer Decision at Aditya Jaya Restaurant in Aceh Besar Regency)

\author{
Era Savia ${ }^{1}$, T. Makmur ${ }^{1}$, Edy Marsudi $^{1^{*}}$ \\ ${ }^{1}$ Program Studi Agribisnis, Fakultas Pertanian, Universitas Syiah Kuala
}

\begin{abstract}
Abstrak - Keputusan konsumen merupakan sebuah tindakan konsumen untuk membeli suatu produk yang dipengaruhi oleh beberapa faktor yaitu kualitas produk, harga, pelayanan dan lokasi Pengambilan keputusan merupakan suatu kegiatan individu yang secara langsung terlibat dalam mendapatkan dan mempergunakan barang yang ditawarkan. Penelitian ini menganalisis pengaruh kualitas produk, harga, pelayanan dan lokasi terhadap keputusan konsumen rumah makan Aditya Jaya di Kabupaten Aceh Besar. Tujuan dari penelitian ini adalah untuk mengetahui pengaruh kualitas produk, harga, pelayanan dan lokasi terhadap keputusan konsumen rumah makan Adiya Jaya. Metode penelitian yang digunakan yaitu metode survey dengan menggunakan kuisioner dan wawancara. Populasi dalam penelitian ini adalah para konsumen rumah makan Aditya Jaya. Sampel yang diambil sebanyak 100 responden dengan menggunakan teknik Non-Probability Sampling dengan pendekatan Accidental sampling, yaitu teknik penentuan sampel berdasarkan kebetulan, yaitu siapa yang kebetulan bertemu dengan peneliti dapat dijadikan sampel. Metode analisis yang digunakan yaitu model analisis Chi-Square dengan menggunakan bantuan program SPSS. Berdasarkan hasil penelitian bahwa kualitas produk, harga dan pelayanan berpengaruh nyata terhadap keputusan konsumen sedangkan lokasi tidak berpengaruh nyata terhadap keputusan konsumen rumah makan Aditya Jaya. Untuk penelitian selanjutnya diharapkan dapat menjelaskan beberapa faktor-faktor lain yang mempengaruhi keputusan konsumen.
\end{abstract}

Kata kunci : Keputusan Konsumen, Kualitas Produk, Harga, Pelayanan, Lokasi.

Abstract - The consumer decision is an act of consumers to buy a product that is affected by several factors such as product quality, price, service and location Decision-making is an activity of individuals who are directly involved in obtaining and using the goods offered. This study analyzes the influence of product quality, price, service and location toward consumers decision Aditya Jaya restaurant in Aceh Besar Regency. The purpose of this study was to determine the effect of product quality, price, service and location of the consumers of Aditya Jaya Restaurant. The method used is a survey method using questionnaires and interviews. The population in this study is the consumers of Aditya Jaya Restaurant. The samples taken as many as 100 respondents using the technique of Non-Probability Sampling with accidental sampling approach, sampling technique based on chance, who happened to meet with the researchers can be sampled. The analytical method used is the model ChiSquare analysis using SPSS. Based on the research that the quality of products, prices and services significantly affect consumer decisions while the location did not significantly affect consumer decisions Aditya Jaya Restaurant. For further research is expected to explain some of the other factors that influence consumer decisions..

Keywords: Consumer Decisions, Product Quality, Price, Services and Location 


\section{PENDAHULUAN}

Usaha rumah makan adalah suatu usaha yang diyakini sebagai salah satu bentuk usaha yang memiliki prospek cukup bagus. Namun sering kali ada usaha yang pada akhirnya gulung tikar akibat tidak mampu mempertahankan jumlah pengunjungnya. Terjadinya suatu kesuksesan usaha dibidang pelayanan makanan dan minuman ini tidak hanya ditentukan oleh jumlah pengunjungnya, tetapi ditentukan oleh kemampuan meningkatkan pertumbuhan konsumennya. Bisnis kuliner menjadi ladang bisnis yang menarik minat banyak orang. Sebagai salah satu upaya untuk memenuhi tuntutan tersebut, maka diperlukan serangkaian strategi yang tepat untuk memenuhi tuntutan keputusan konsumen agar konsumen tidak lari kepada pesaing lain.

Pemahaman perusahaan berawal dari produk, selanjutnya disesuaikan dengan price, promotion dan place. Tingkat persaingan yang ketat antara perusahaan menyebabkan perusahaan harus benar-benar memikirkan strategi yang tepat dalam menghadapi persaingan tersebut. Munfaat (2003) menyatakan ada lima sumber kekuatan persaingan yang harus diantisipasi dan dipahami perusahaan agar dapat menyusun strategi bersaing sehingga mampu memenangkan persaingan. Kelima kekuatan tersebut adalah ancaman yang datang dari suplier, ancaman pendatang baru, ancaman dari konsumen, ancaman dari perusahaan yang menghasilkan produk substitusi, dan ancaman dari perusahaan sejenis.

Harga juga merupakan variabel penting dalam pemasaran. Harga yang rendah atau harga yang terjangkau menjadi pemicu untuk meningkatkan kinerja pemasaran (Ferdinand, 2002). Namun harga juga dapat menjadi indikator kualitas dimana suatu produk dengan kualitas tinggi akan berani dipatok dengan harga yang tinggi pula

Faktor lokasi juga merupakan faktor yang menentukan keberhasilan suatu bisnis. Menurut Raharjani (2005), strategi lokasi adalah salah satu determinan yang paling penting dalam perilaku konsumen, perusahaan harus memilih lokasi yang strategis dalam menempatkan tokonya (Rumah Makan) di suatu kawasan / daerah yang dekat dengan keramaian dan aktivitas masyarakat. Karena apabila terjadi kesalahan dalam memilih lokasi akan berpengaruh besar pada kelangsungan hidup pemilik rumah makan.

Selain lokasi, pelayanan juga dapat memuaskan konsumen akan berdampak terjadinya pembelian berulang-ulang yang berarti akan terjadi peningkatan penjualan. Dengan pelayanan yang baik dapat menciptakan kepuasan dan loyalitas konsumen serta membantu menjaga jarak dengan pesaing (Kotler, 1999). Jika perusahaan tidak dapat memenuhi maka akan menimbulkan ketidakpuasan. Biasanya konsumen menilai kepuasan atau ketidakpuasan terhadap suatu produk dengan cara membandingkan kinerja atau hasil yang dia rasakan dibandingkan dengan harapannya.

Rumah Makan Aditya Jaya merupakan sebuah perusahaan jasa yang berlokasi di Jalan Lama Blang Bintang (belakang pertamina bandara Sultan Iskandar Muda) Gampong Cot Mancang Kecamatan Kuta Baro KabupatenAceh Besar. Sofyan Hasan merupakan pemilik dari Rumah Makan Aditya Jaya, rumah makan ini bertujuan memberikan kepuasan pada konsumen, untuk itu Rumah Makan Aditya jaya harus memiliki daya saing yang tinggi agar mampu memenuhi keinginan konsumen agar tercipta loyalitas yang tinggi dan konsumen pengunjung rumah makan Aditya Jaya diperkirakan dalam setiap harinya mencapai 100 orang dari semua jenis kalangan. Ketertarikan konsumen terhadap menu khas Aceh yang disediakan rumah makan ini menyebabkan konsumen memberikan julukan untuk rumah makan ini adalah "Ayam Pramugari" dikarenakan lokasi usaha dekat dengan bandara dan bentuk kaki ayam ini panjang seperti layaknya pramugari. Rumah makan Aditya Jaya menawarkan beberapa menu khas Aceh diantaranya Ayam Goreng Kampong, Kari Ayam, Gulai Kambing, Air Timun Serut, Air Pepaya Serut dan Jus Jeruk Peras 
Dari uraian latar belakang di atas penulis tertarik melakukan penelitian mengenai analisis pengaruh kualitas produk, harga, pelayanan dan lokasi terhadap keputusan konsumen rumah makan Aditya Jaya di Kabupaten Aceh Besar. Adapun tujuan dari penelitian ini adalah untuk mengetahui pengaruh kualitas produk, harga, pelayanan dan lokasi terhadap keputusan konsumen rumah makan Aditya Jaya di Kabupaten Aceh Besar.

\section{METODE PENELITIAN}

Lokasi penelitian ini dilakukan pada rumah makan Aditya Jaya yang terletak di Jalan Lama Blang Bintang Gampong Cot Mancang Kecamatan Kuta Baro Kabupaten Aceh Besar. Objek penelitian ini terfokus pada konsumen rumah makan Aditya Jaya. Adapun ruang lingkup penelitian ini terbatas pada pengaruh pada kualitas produk, harga, pelayanan dan lokasi terhadap keputusan konsumen rumah makan Aditya Jaya di Kabupaten Aceh Besar.

Populasi dalam penelitian ini adalah para konsumen rumah makan Aditya Jaya di Aceh Besar. Jumlah sampel yang digunakan adalah 100 orang responden. Pada penelitian ini populasinya sangat besar dan jumlahnya tidak diketahui maka untuk menentukan ukuran sampel penelitian dari populasi tersebut dapat digunakan dengan rumus slovin (Sugiyono, 2004).

$$
\begin{aligned}
n & =\frac{z^{2}}{4(m o e)^{2}} \\
n & =\frac{(1.96)^{2}}{4(0,1)^{2}} \\
& =96,6 \text { dibulatkan menjadi } 100 \text { responden }
\end{aligned}
$$

Dimana:

n $\quad$ jumlah sampel

$\mathrm{z} \quad=$ Tingkat distribusi normal pada taraf signifikan $5 \%(1,96)$

Moe = Margin of error atau kesalahan maksimum yang bias ditoleransi, biasanya sebesar $10 \%$

Penentuan sampel dalam penelitian ini menggunakan Non Probability Sampling, yaitu semua elemen dalam populasi tidak memiliki kesempatan yang sama untuk dipilih menjadi sampel (Ferdinand, 2006). Hal ini dilakukan karena mengingat keterbatasan waktu yang ada. Metode pengambilan sampelnya menggunakan Accidental sampling, teknik penentuan sampel berdasarkan kebetulan, yaitu siapa yang kebetulan bertemu dengan peneliti dapat dijadikan sampel jika orang tersebut sesuai atau cocok sebagai sumber data (Sugiyono, 2000).

Metode yang digunakan dalam penelitian ini adalah metode survey. Metode survey adalah metode yang mengambil sampel dari satu populasi dan menggunakan kuesioner sebagai alat pengumpulan data yang pokok (Singarimbum dan Effendi, 2003). Kuesioner dalam penelitian ini digunakan sebagai pengumpul data primer. Data sekunder yang digunakan dalam penelitian ini berupa studi kepustakaan, jurnal, skripsi, literatur-literatur yang berkaitan dengan permasalahan, dan informasi dokumentasi lain yang dapat diambil melalui system On-line (Internet) yang berkaitan dengan masalah yang diteliti. 
Metode analisis yang digunakan penelitian ini adalah metode analisis deskriptif kualitatif dan kuantitatif. Analisis kualitatif ini digunakan untuk membahas dan menerangkan hasil penelitian tentang berbagai gejala atau kasus yang dapat diuraikan dengan kalimat. Dalam penelitian ini analisis kualitatif tersebut adalah hasil pertanyaan responden dari sangat tidak setuju sampai dengan sangat setuju, kemudian jawaban dengan skor terbanyak yang disimpulkan.

Untuk mendapatkan data kuantitatif, digunakan skala Likert yang diperoleh dari daftar pertanyaan (kuesioner) yang digolongkan kedalam lima tingkatan. Penentuan nilai (score) pilihan dibatasi dengan jarak interval 1. Skor dari pilihan tersebut antara lain 1, 2, 3, 4 dan 5. Komposisi dari masing- masing nilai pilihan tersebut adalah sebagai berikut (Sugiyono, 2004):

Tabel 1. Skor Pengukuran Kuesioner Terhadap Responden Rumah Makan Aditya Jaya

\begin{tabular}{|c|c|}
\hline Pilihan & Skor \\
\hline Sangat Tidak Setuju & 1 \\
\hline Tidak Setuju & 2 \\
\hline Cukup Setuju & 3 \\
\hline Setuju & 4 \\
\hline Sangat Setuju & 5 \\
\hline
\end{tabular}

Sumber: Sugiyono, (2004)

Untuk menguji pengaruh antara variabel faktor terhadap keputusan konsumen digunakan uji statistic dengan menggunakan Chi-Square (Priyatno, 2005):

Dimana:

$$
\mathrm{X}^{2}=\sum_{i=1}^{k} \frac{(f 0-f h) 2}{f h}
$$

F0 = Banyaknya observasi

Fh = Banyaknya observasi yang diharapkan

Derajat kebebasan (df) adalah: (jumlah baris-1) (jumlah kolom-1)

Dengan ketentuan:

Jika $\mathrm{X}_{\text {hitung }}^{2}>\mathrm{X}_{\text {tabel }}^{2}{ }^{(\mathrm{B}-1)(\mathrm{k}-1)}$, pada taraf 0,05 maka terima $\mathrm{H}_{\mathrm{a}}$ tolak $\mathrm{H}_{0}$

Jika $\mathrm{X}_{\text {hitung }}^{2}<\mathrm{X}_{\text {tabel }}^{2}{ }^{(\mathrm{B}-1)(\mathrm{k}-1)}$, pada taraf 0,05 maka terima $\mathrm{H}_{0}$ tolak $\mathrm{H}_{\mathrm{a}}$

Dengan Hipotesis sebagai berikut:

$\mathrm{H}_{\mathrm{a}}=$ variable kualitas produk, harga, pelayanan dan lokasi berpengaruh terhadap keputusan

konsumen rumah makan.

$\mathrm{H}_{0}=$ variable kualitas produk, harga, pelayanan dan lokasi tidak berpengaruh terhadap

keputusan konsumen rumah makan.

\section{Karakteristik Responden}

\section{HASIL DAN PEMBAHASAN}

Berdasarkan Tabel 2 dapat diketahui bahwa untuk umur responden yang terbanyak adalah yang berumur antara 20 - 29 tahun sebanyak 44 (44\%), diikuti dengan usia responden kurang dari 30 - 39 tahun sebanyak 19 orang (19\%). Jumlah responden yang terendah adalah 
pada umur $>50$ tahun yaitu sebanyak 8 orang (8\%). Proporsi demikian menunjukkan adanya distribusi umur yang mencolok adalah pada umur yang masih relatif muda. Hal ini disebabkan karena pada umur tersebut biasanya seseorang memiliki kesenangan yang cukup banyak dibanding pada umur tua.

Tabel 2. Kategori Umur Responden di Rumah Makan Aditya Jaya Pada Tahun 2016

\begin{tabular}{|c|l|c|c|}
\hline No & \multicolumn{1}{|c|}{ Umur } & Jumlah Responden & Persentase \\
\hline 1. & $<20$ tahun & 14 & 14 \\
\hline 2. & $20-29$ tahun & 44 & 44 \\
\hline 3. & $30-39$ tahun & 19 & 19 \\
\hline 4. & $40-49$ tahun & 15 & 8 \\
\hline 5. & $>50$ tahun & 8 & 100 \\
\hline
\end{tabular}

Sumber: Data primer yang diolah, 2016

Diketahui bahwa untuk jenis kelamin perempuan memiliki jumlah yang lebih banyak dibanding jenis kelamin laki-laki yaitu 62 perempuan dan 38 laki-laki. Hal ini menunjukkan bahwa perempuan memiliki aktivitas dan keinginan kuliner yang lebih besar dibandingkan laki-laki.

Tabel 3. Jenis Kelamin Responden di Rumah Makan Aditya Jaya Pada Tahun 2016

\begin{tabular}{|c|l|c|c|}
\hline No & Jenis Kelamin & Jumlah Responden & Persentase \\
\hline 1. & Laki-Laki & 38 & 38 \\
\hline 2. & Perempuan & 62 & 62 \\
\hline \multicolumn{2}{c|}{ Total } & 100 & 100 \\
\hline
\end{tabular}

Sumber: Data primer yang diolah, 2016

Pada tabel diatas menunjukkan bahwa sebanyak 56 orang $(56 \%)$ berpendidikan Perguruan Tinggi yaitu sarjana dan D3, diikuti oleh responden yang berpendidikan SMA (Sekolah Menengah Atas) sebanyak 27 orang (27\%). Hal ini memberikan penjelasan bahwa konsumen berpendidikan Perguruan Tinggi merupakan konsumen yang cukup potensial dalam pembelian

Tabel 4. Tingkat Pendidikan Terakhir Responden di Rumah Makan Aditya Jaya Pada Tahun 2016

\begin{tabular}{|c|l|c|c|}
\hline No & \multicolumn{1}{|c|}{ Pendidikan } & Jumlah Responden & Persentase \\
\hline 1. & SD & 2 & 2 \\
\hline 2. & SMP & 12 & 12 \\
\hline 3. & SMA & 27 & 27 \\
\hline 4. & D3 & 18 & 38 \\
\hline 5. & Sarjana & 38 & 100 \\
\hline \multicolumn{2}{|r|}{ Total } & 100 & \\
\hline
\end{tabular}


Deskripsi responden berdasarkan pekerjaan adalah sebagai berikut:

Tabel 5. Jenis Pekerjaan Responden di Rumah Makan Aditya Jaya Pada Tahun 2016

\begin{tabular}{|c|l|c|c|}
\hline No & \multicolumn{1}{|c|}{ Pekerjaan } & Jumlah Responden & Persentase \\
\hline 1. & Pelajar/Mahasiswa & 29 & 29 \\
\hline 2. & PNS & 22 & 21 \\
\hline 3. & Swasta & 21 & 24 \\
\hline 4. & Wiraswasta & 24 & 4 \\
\hline 5. & Lain-Lain & 4 & 100 \\
\hline
\end{tabular}

Sumber: Data primer yang diolah, 2016

Berdasarkan tabel diatas dapat disimpulkan bahwa jumlah responden terbanyak berdasarkan jenis pekerjaan adalah pelajar/mahasiswa sebanyak 29 orang (29\%), diikuti dengan jenis pekerjaan wiraswasta sebanyak 24 orang (24\%). Jumlah responden terendah adalah jenis pekerjaan lain-lain seperti Ibu Rumah Tangga sebanyak orang 4 orang (4\%).

Deskripsi responden berdasarkan pendapatan adalah sebagai berikut:

Tabel 6. Tingkat Pendapatan Perbulan Responden di Rumah Makan Aditya Jaya Pada Tahun 2016

\begin{tabular}{|c|l|c|c|}
\hline No & \multicolumn{1}{|c|}{ Pendapatan } & Jumlah Responden & Persentase \\
\hline 1. & $<$ Rp. 100.000 & 2 & 2 \\
\hline 2. & Rp. $100.000-$ Rp. 500.000 & 14 & 14 \\
\hline 3. & Rp. 500.000- Rp. 1.000.000 & 30 & 30 \\
\hline 4. & Rp. 1.000.000- Rp. 5.000.000 & 50 & 50 \\
\hline 5. & $>$ Rp. 5.000.000 & 4 & 4 \\
\hline & Total & 100 & 100 \\
\hline
\end{tabular}

Sumber: data primer yang diolah, 2016

Berdasarkan tabel diatas menunjukkan bahwa sebagian responden adalah denganpendapatan dari Rp. 1.000 .000 - Rp. 5.000 .000 yaitu sebanyak 50 orang(50\%),diikuti oleh responden pendapatan kurang Rp. 500.000 - Rp. 1.000 .000 yaitu sebanyak 30 orang 
(30\%). Hal ini menunjukkan bahwa kalangan orang yang memiliki pendapatan yangtidak terlalu tinggi sebagai salah satu kelompok konsumen Rumah Makan Aditya Jaya.

\section{Analisis Deskriptif}

Untuk mencari nilai rentang skor menggunakan rumus sebagai berikut:

$\mathrm{RS}=(\mathrm{m}-\mathrm{n}) / \mathrm{k}$

$\mathrm{RS}=(5-1) / 5=0,80$

Dimana:

$\mathrm{RS}=$ rentang skala

$\mathrm{m}=$ skor maksimal

$\mathrm{n}=$ skor minimal

$\mathrm{k}=$ jumlah kategori

Tabel 7. Hasil Tanggapan Responden dari Setiap Faktor

\begin{tabular}{|l|c|}
\hline \multicolumn{1}{|c|}{ Variabel } & Rata-Rata Keseluruhan Skor \\
\hline Kualitas Produk & 3.92 (Tinggi) \\
\hline Harga & 3,83 (Tinggi) \\
\hline Pelayanan & 3,90 (Tinggi) \\
\hline Lokasi Keputusan Konsumen & 3,35 (Sedang) \\
\hline \multicolumn{2}{c}{ Kengat Tinggi) } \\
\hline
\end{tabular}

Sumber: Data primer yang diolah, 2016

Berdasarkan tabel diatas dapat diketahui bahwa faktor kualitas produk, harga dan pelayanan menempati kategori tinggi, lokasi menempati kategori sedang dan keputusan konsumen menempati kategori sangat tinggi.

\section{Pengujian Validitas}

Pada Tabel 8 menunjukkan bahwa semua indikator yang digunakan untuk mengukur variabel-variabel pada penelitian ini mempunyai nilai koefisien korelasi yang lebih besar dari nilai $r$ tabel untuk sampel 100 responden yaitu 0,197. Nilai $r$ hitung setiap indikator dapat dilihat pada Tabel 8. Hal ini menunjukkan semua indikator setiap variabel tersebut adalah valid. 
Tabel 8. Hasil Pengujian Validasi Data Penelitian di Rumah Makan Aditya Jaya Pada Tahun 2016

\begin{tabular}{|c|c|c|c|c|}
\hline No & Indikator & r hitung & $\mathrm{r}$ tabel & Keterangan \\
\hline \multirow{4}{*}{1} & Kualitas Produk : & & & \\
\hline & Indikator 1 & 0,699 & 0,197 & Valid \\
\hline & Indikator 2 & 0,735 & 0,197 & Valid \\
\hline & Indikator 3 & 0,688 & 0,197 & Valid \\
\hline \multirow{4}{*}{2} & Harga : & & & \\
\hline & Indikator 1 & 0,760 & 0,197 & Valid \\
\hline & Indikator 2 & 0,784 & 0,197 & Valid \\
\hline & Indikator 3 & 0,540 & 0,197 & Valid \\
\hline \multirow{4}{*}{3} & Pelayanan: & & & \\
\hline & Indikator 1 & 0,674 & 0,197 & Valid \\
\hline & Indikator 2 & 0,824 & 0,197 & Valid \\
\hline & Indikator 3 & 0,617 & 0,197 & Valid \\
\hline \multirow{4}{*}{4} & Lokasi : & & & \\
\hline & Indikator 1 & 0,825 & 0,197 & Valid \\
\hline & Indikator 2 & 0,754 & 0,197 & Valid \\
\hline & Indikator 3 & 0,582 & 0,197 & Valid \\
\hline \multirow{4}{*}{5} & Keputusan Pembelian : & & & \\
\hline & Indikator 1 & 0,766 & 0,197 & Valid \\
\hline & Indikator 2 & 0,809 & 0,197 & Valid \\
\hline & Indikator 3 & 0,765 & 0,197 & Valid \\
\hline
\end{tabular}

Sumber: data primer yang diolah, 2016 


\section{Uji Reliabilitas}

Pada Tabel 9 hasil uji reliabilitas menunjukkan bahwa semua variabel penelitian mempunyai koefisien Alpha lebih besar dari 0,60, sehingga dapat dikatakan bahwa semua indikator masing-masing variabel dari kuesioner adalah reliabel, sehingga untuk selanjutnya indikator-indikator pada masing-masingkonsep variabel sebagai alat ukur.

Tabel 9. Hasil Uji Reliabilitas Data Penelitian di Rumah Makan Aditya Jaya Pada Tahun 2016

\begin{tabular}{|l|c|c|}
\hline \multicolumn{1}{|c|}{ Variabel } & Alpha & Keterangan \\
\hline Kualitas Produk & 0,753 & Reliabel \\
\hline Harga & 0,702 & Reliabel \\
\hline Pelayanan & 0,757 & Reliabel \\
\hline Lokasi & 0,699 & Reliabel \\
\hline Keputusan Pembelian & 0,787 & Reliabel \\
\hline
\end{tabular}

Sumber: data primer yang diolah, 2016

\section{Pengaruh Kualitas Produk Terhadap Keputusan Konsumen}

Berdasarkan hasil uji Chi-Square diperoleh hasil yang dapat dilihat pada tabel berikut:

Tabel 10. Hasil Uji Chi-Square Pada Pengaruh Kualitas Produk Terhadap Keputusan Konsumen di Rumah Makan Aditya Jaya Pada Tahun 2016

\begin{tabular}{|c|c|c|c|}
\hline & Value & Df & Asymp. Sig. (2-sided) \\
\hline Pearson Chi-Square & $10.745^{\mathrm{a}}$ & 6 & .071 \\
\hline Likelihood Ratio & 7.921 & 6 & .154 \\
\hline Linear-by-Linear & 3.510 & 1 & .022 \\
\hline Association & & & \\
\hline $\mathrm{N}$ of Valid Cases & 100 & & \\
\hline
\end{tabular}

Sumber: Data Primer yang diolah, 2016

Berdasarkan Tabel 10 dapat dilihat nilai $\mathrm{X}^{2}$ hitungsebesar 10.745 sedangkan $\mathrm{X}^{2}$ tabel pada taraf signifikansi 0,05 dan derajad bebas (df) 6 adalah sebesar 9.488. Oleh karena itu, $X^{2}{ }_{\text {hitung }}$ $>\mathrm{X}_{\text {tabel }}$, dan dapat diketahui juga dari nilai Asymp. Sig yang diperoleh adalah 0,017 yang lebih kecil dari 0,05 yang menjelaskan bahwa signifikan, maka keputusan yang dapat diambil adalah terima Ha. Hasil dari uji Chi-Square terhadap variabel kualitas produk menyatakan bahwa terdapat pengaruh antara variabel kualitas produk terhadap keputusan konsumen rumah makan Aditya Jaya. Berdasarkan hasil tersebut adanya respon positif yang diberikan oleh konsumen terhadap rumah makan Aditya Jaya dalam memberikan makanan yang enak, porsi yang sesuai dan penyajian yang higienis.

\section{Pengaruh Variabel Harga Terhadap Keputusan Konsumen}

Berdasarkan Tabel 11 dapat dilihat nilai $\mathrm{X}^{2}{ }_{\text {hitung }}$ sebesar 11.734 sedangkan $\mathrm{X}_{\text {tabel }}^{2}$ pada taraf signifikan 0,05 dan derajad bebas (df) 6 adalah 9. 488. Oleh karena itu, $X^{2}{ }_{\text {hitung }}>X^{2}$ tabel, dan dapat diketahui juga dari nilai Asymp. Sig yang diperoleh adalah 0,068 yang lebih kecil dari 0,05 yang menjelaskan bahwa signifikan, maka keputusan yang dapat diambil adalah terima Ha. Hasil dari uji Chi-Square terhadap variabel harga menyatakan bahwa terdapat pengaruh antara variabel harga terhadap keputusan konsumen rumah makan Aditya Jaya. Hal ini menunjukkan bahwa harga masih terjangkau bagi semua kalangan konsumen, dengan 
mempertahankan nilai harga setiap produk yang dihasilkan maka akan meningkatkan pula keputusan dalam pembelian di rumah makan Aditya Jaya.

Tabel 11. Hasil Uji Chi-Square Pada Pengaruh Harga Terhadap Keputusan Konsumen di Rumah Makan Aditya Jaya Pada Tahun 2016

\begin{tabular}{|l|r|c|c|}
\hline & \multicolumn{1}{|c|}{ Value } & Df & Asymp. Sig. (2-sided) \\
\hline Pearson Chi-Square & $11.734^{\mathrm{a}}$ & 6 & .068 \\
Likelihood Ratio & 9.568 & 6 & .144 \\
Linear-by-Linear & 4.751 & 1 & .029 \\
Association & 100 & & \\
N of Valid Cases & & & \\
\hline
\end{tabular}

Sumber: data primer yang diolah, 2016

\section{Pengaruh Variabel Pelayanan Terhadap Keputusan Konsumen}

Berdasarkan Tabel 12 diatas dapat dilihat nilai X2hitung sebesar 11.125 sedangkan X2tabel pada taraf signifikan 0,05 dan derajad bebas (df) 4 adalah 5,991. Oleh karena itu, X2hitung > X2tabel, dan dapat diketahui juga dari nilai Asymp. Sig yang diperoleh adalah 0,025 yang lebih kecil dari 0,05 yang menjelaskan bahwa signifikan, maka keputusan yang dapat diambil adalah terima Ha. Hasil dari uji Chi-Square terhadap variabel pelayanan menyatakan bahwa terdapat pengaruh antara variabel pelayanan terhadap keputusan konsumen rumah makan Aditya Jaya. Hal ini menunjukkan bahwa semakin baik tingkat pelayanan yang diberikan di rumah makan ini makan akan semakin membuat konsumen nyaman dan puas terhadap fasilitas-fasilitas yang tersedia.

Tabel 12. Hasil Uji Chi-Square Pada Pengaruh Pelayanan Terhadap Keputusan Konsumen di Rumah Makan Aditya Jaya Pada Tahun 2016

\begin{tabular}{|l|c|c|c|}
\hline & Value & Df & Asymp. Sig. (2-sided) \\
\hline Pearson Chi-Square & $11.125^{\mathrm{a}}$ & 4 & .025 \\
Likelihood Ratio & 8.847 & 4 & .065 \\
Linear-by-Linear & 3.055 & 1 & .080 \\
Association & 100 & & \\
N of Valid Cases & & & \\
\hline
\end{tabular}

Sumber: Data Primer yang Diolah, 2016 


\section{Pengaruh Variabel Lokasi Terhadap Keputusan Konsumen}

Berdasarkan tabel 19 diatas dapat dilihat nilai $\mathrm{X}^{2}$ hitung sebesar 8.447 sedangkan $\mathrm{X}^{2}$ tabel pada taraf signifikan 0,05 dan derajad bebas (df) 6 adalah 9.488. Oleh karena itu, $\mathrm{X}^{2}{ }_{\text {hitung }}<$ $\mathrm{X}_{\text {tabel }}^{2}$, dan dapat diketahui juga dari nilai Asymp. Sig yang diperoleh adalah 0,207 yang lebih besar dari 0,05 yang menjelaskan bahwa tidak signifikan, maka keputusan yang dapat diambil adalah tolak Ha. Hasil dari uji Chi-Square terhadap variabel pelayanan menyatakan bahwatidak ada pengaruh antara variabel lokasi terhadap keputusan konsumen rumah makan Aditya Jaya. Berdasarkan hasil uji Chi-Square diperoleh hasil yang dapat dilihat pada tabel berikut:

Tabel 13. Hasil Uji Chi-Square Pada Pengaruh Lokasi Terhadap Keputusan Konsumen di Rumah Makan Aditya Jaya Pada Tahun 2016

\begin{tabular}{|l|r|r|r|}
\hline & \multicolumn{1}{|c|}{ Value } & Df & Asymp. Sig. (2-sided) \\
\hline Pearson Chi-Square & $8.447^{\mathrm{a}}$ & 6 & .207 \\
Likelihood Ratio & 9.687 & 6 & .138 \\
Linear-by-Linear & 3.462 & 1 & .063 \\
Association & 100 & & \\
N of Valid Cases & & & \\
\hline
\end{tabular}

Sumber: data primer yang diolah, 2016

\section{KESIMPULAN DAN SARAN}

Faktor Kualitas Produk, Harga, dan Pelayanan berpengaruh terhadap Keputusan Konsumen rumah makan Aditya Jaya. Hal ini dibuktikan dengan nilai $\mathrm{X}_{\text {hitung }}^{2}<\mathrm{X}_{\text {tabel, }}^{2}$ yaitu nilai $\mathrm{X}^{2}$ diatas 9.488 dan nilai signifikan dibawah 0,05 .

Faktor lokasi tidak berpengaruh terhadap Keputusan Konsumen rumah makan Aditya

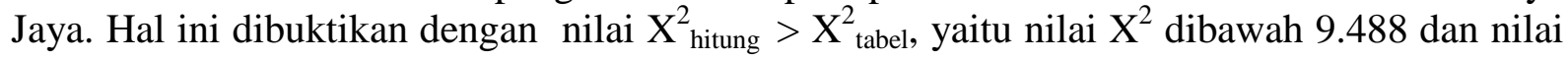
signifikan diatas 0,05 .

Berdasarkan hasil penelitian diketahui bahwa variabel harga mendapat penilaian dari responden dalam kategori tinggi. Oleh karena itu, Rumah Makan Aditya Jaya disarankan untuk selalu memonitor harga yang ditetapkan, agar harga tersebut tidak terlalu tinggi, sehingga semakin tepat usaha dalam menentukan penetapan harga, keputusan pembelian juga semakin tinggi. Selanjutnya sebaiknya menambahkan menu-menu andalan baru agar kualitas produk yang dihasilkan semakin membuat konsumen merasa puas. Untuk lokasi disarankan agar membuka cabang di dekat perkotaan dengan lingkungan aman, tentram dan sejuk.

\section{DAFTAR PUSTAKA}

Ferdinand, Augusty. 2002. Structural Equation Mdelling dalam Penelitian Manajemen. FE UNDIP. Semarang 
Ferdinand, Augusty. 2006. Metode Penelitian Manajemen: Pedoman Penelitian untuk Penulisan Skripsi, Tesis, dan Disertasi ILme Manajemen. FE UNDIP. Semarang

Kotler,P. 1999. Manajemen Pemasaran di Indonesia. Salemba Empat. Jakarta

Pratikto, S.B. 2003. Analisis Tingkat Kepuasan Konsumen Terhadap Pelayanan Restoran Famili Resto Cibubur. Skripsi. Departemen Ilmu-ilmu Sosial Ekonomi Pertanian. Fakultas Pertanian. Insititut Pertanian Bogor.

Raharjani, Jeni. 2005. Analisis Faktor yang Mempengaruhi Keputusan Pemilihan Pasar Swalayan Sebagai Tempat Berbelanja. Jurnal Studi Manajemen dan Organisasi, Vol. 2, No. 1

Singarimbum, M dan Effendi, S. 2003. Metode Penelitian Survei. LP3ES. Jakarta

Sugiyono. 2006. Statistic untuk Penelitian. CV. Alfabeta. Bandung.

Sugiyono. 2004. Metode Penelitian Bisnis. CV. Alfabeta. Bandung. 